\title{
INSTITUTIONAL SOURCES OF BUSINESS POWER
}

\author{
By MARIUS R. BUSEMEYER and KATHLEEN THELEN
}

\begin{abstract}
Recent years have seen a revival of debates about the role of business and the sources of business power in postindustrial political economies. Scholarly accounts commonly distinguish between structural sources of business power, connected to its privileged position in capitalist economies, and instrumental sources, related to direct forms of lobbying by business actors. The authors argue that this distinction overlooks an important third source of business power, which they conceptualize as institutional business power. Institutional business power results when state actors delegate public functions to private business actors. Over time, through policy feedback and lock-in effects, institutional business power contributes to an asymmetrical dependence of the state on the continued commitment of private business actors. This article elaborates the theoretical argument behind this claim, providing empirical examples of growing institutional business power in education in Germany, Sweden, and the United States.
\end{abstract}

\section{INTRODUCTION}

7 HIS article explores the sources and dynamics of a distinctive form of business power in contemporary capitalism. Classic accounts of business power make a broad distinction between the structural power of capital and its instrumental power. Structural power arguments emphasize the privileged position occupied by business interests in market economies, which rely on the private investment decisions of business actors to sustain growth and employment. ${ }^{1}$ Instrumental power arguments, by contrast, draw attention to more direct forms of business influence, such as lobbying and making campaign contributions to favored candidates to secure particular policy outcomes.

These literatures have taught us a great deal about business power. But the existing scholarship has largely overlooked a third long-standing but increasingly important source of business power in advanced capitalism, which we label institutional business power. This type of power arises when policymakers invite or allow private actors to share in the delivery of public responsibilities, setting in motion feedback effects that

${ }^{1}$ Lindblom 1977. 
over time enhance the power of private interests vis-à-vis publicly accountable government actors.

The practice of assigning parapublic responsibilities to representatives of organized business (and labor) is a well-known and long-standing feature of Europe's corporatist political economies. Although some of the literature in this area articulates a concern about the potential capture of public authority by private interests, ${ }^{2}$ the corporatism literature as a whole tends to emphasize the benefits of "social partnership" and the benign, even beneficial effects of these arrangements. ${ }^{3}$ Meanwhile, the liberalization of public services has also produced different forms of public-private partnerships in liberal Anglo-Saxon countries. Students of American politics have drawn attention to the way in which the private provision of key social benefits often precludes more egalitarian public options. ${ }^{4}$ But because these observations are typically invoked to underscore the peculiarities of the US political economy relative to the more socially embedded varieties of capitalism in Europe, they tend to obscure key similarities in how the institutional power of business unfolds across the whole range of postindustrial democracies.

Our analysis provides a unified framework for understanding the power dynamics that underlie public-private governance arrangements across the rich democracies. We show how these arrangements foster asymmetric dependencies of the state on the continued contribution of business actors in ways that, over time, tilt the public-private balance increasingly in favor of business interests. The need to understand the power dynamics unleashed by such arrangements is, if anything, more urgent in the context of a general trend-across virtually all the rich democracies - toward the outsourcing of public functions to private enterprises, often justified with reference to efficiency and consumer choice.

We situate our analysis in the context of a growing literature on business power in advanced capitalism to show how the forms of power we explore are not well captured by classic notions of structural and instrumental power. Unlike structural power, institutional power isn't a generic feature of capitalist economies, and unlike instrumental power, it's not directed at promoting or preventing particular instances of policy change via lobbying. Instead, institutional business power is distinctive in that it's endogenous to policy design choices-that is, it essentially

\footnotetext{
${ }^{2}$ See, e.g., Panitch 1977; Streeck and Kenworthy 2005, 455.

${ }^{3}$ See, e.g., Lijphart 1999; Katzenstein 1985.

${ }^{4}$ E.g., Hacker 2004; Mettler 2011.
} 
represents the feedback effects of past policy choices. ${ }^{5}$ We identify three general mechanisms through which institutional business power takes root in the rich democracies-delegation, deregulation, and accretion. In all three, what's initially a voluntary choice on the part of state actors to share public responsibilities sets in motion feedback effects that enhance and entrench the influence of business over time.

In what follows, we first provide a brief review of the literature on business power, noting the recent resurgence of scholarly interest in this subject and detailing the accomplishments and the gaps in both classic and contemporary treatments. Next, we explore the phenomenon of institutional business power as a crucial and hitherto overlooked dimension through which the power of business has grown in democratic capitalist political economies. We provide empirical illustrations of our argument in the form of short case studies of policy developments in Germany, Sweden, and the United States. We focus on the field of primary and secondary education as a particularly instructive case, because ex ante, there's no compelling reason why the state should delegate public responsibilities to business actors in a field with a long tradition, in most countries, of direct public provision. That we see an increase in institutional power in this policy area suggests that such an increase is likely to matter even more in policy areas in which the influence of business is greater to begin with. We document commonalities and parallel trends in three country cases that represent "most different cases" spanning the three worlds of welfare capitalism and distinct varieties of capitalism. ${ }^{6}$ Our concluding section summarizes the argument and draws out its implications for the study of business power in the current period.

\section{Business Power in Capitalist Democracies}

Arguments about the structural power of business commonly center on Charles Lindblom's well-known thesis about its privileged position in democratic capitalism. According to Lindblom, businesspeople are similar to public officials in that their investment decisions have large consequences for society as a whole, affecting growth and employment and, by extension, the distribution of income and wealth. ${ }^{7}$ But unlike democratically accountable public officials, businesses make private investment decisions, so in a market economy governments can't force

\footnotetext{
${ }^{5}$ We thank an anonymous reviewer for this formulation.

${ }^{6}$ Esping-Andersen 1990; Hall and Soskice 2001.

${ }^{7}$ Lindblom 1977.
} 
them to do their bidding. Instead, governments must offer inducements to ensure that private investment decisions will have beneficial (side) effects for society at large, especially by creating employment opportunities. ${ }^{8}$ Lindblom emphasizes that to exert their power, businesspeople don't need to organize politically or to act in a coordinated manner: "Businesspeople do not have to debate whether or not to impose the penalty. They need to do no more ... than tend to their own business, which means that, without thought of effecting a punishment on us, they restrict investment and jobs simply in the course of being prudent managers of their enterprises."

Lindblom's analysis resonates with earlier arguments from the socalled community power debate ${ }^{10}$ in emphasizing that the range of issues that are openly discussed and contested during policy-making processes is usually only a subset of all possible issues. Policymakers shy away from ambitious reforms that could trigger a negative counterreaction from business, thus narrowing the range of issues and options that make it onto the political agenda in the first place.

In the 1980s and 1990s, arguments about the structural power of business were heavily criticized as either nonfalsifiable or false. As Pepper Culpepper writes, "Structural power became as suspect in political science as conspiracy theories, with which it appeared to share problems of falsifiability." ${ }^{11}$ But arguments by some that power theories could not be falsified didn't stop others from claiming to do just that. David Vogel, for example, argues that the empirical implications of the "structural dependency thesis" squared badly with existing evidence. ${ }^{12} \mathrm{He}$ cites a number of policy reforms in the 1970s and 1980s in the United States, such as reforms in environmental legislation and consumer protection, which passed despite the vocal opposition of business. ${ }^{13} \mathrm{Vo}_{\mathrm{O}}$ gel also points to significant differences in the power of business actors across countries, saying those in Europe's social democracies appeared to be considerably less powerful than their North American counterparts. ${ }^{14} \mathrm{He}$ takes these demonstrations of the variability of employer power as evidence of the bankruptcy of approaches that conceived of business power in structural terms - that is, as a fixed attribute of all capitalist political economies.

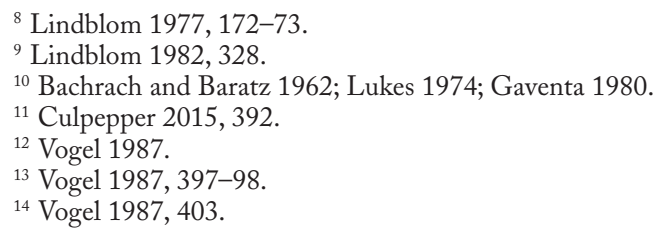


In a sense, Vogel's reference to cross-national variation in the power of business set the ground for the influential debates in political economy that took off in the 1990s on the subject of distinct varieties of capitalism (Voc) in the rich democracies. But the flourishing literature in this area didn't take up Vogel's core argument. Indeed, it mostly sidestepped the issue of business power. For instance, in the original Voc framework, ${ }^{15}$ the essential difference between liberal and coordinated market economies wasn't that business was more powerful in one type of capitalism than the other, but rather that business actors relied on different types of coordination-via market or nonmarket institutions - for their activities. The issue of business power, and how it might vary across different institutional arrangements, remained in the background.

Voc's main foil, power resource theory, took issue with the voluntarist view of institutions at the core of voc theory, and explicitly emphasized class conflict and power in capitalism. ${ }^{16}$ But the power resources that gave the theory its name had more to do with the power of labor than that of business. Scholars in this school operationalized and measured power almost exclusively in terms of the resources-industrial, organizational, and political-that labor could bring to bear in conflicts with capital. ${ }^{17}$ The thrust of this line of theorizing wasn't so much to assess the sources of business power but rather to point out that in coordinated market economies employers were more constrained (and by implication, less powerful) than their counterparts in liberal market economies. ${ }^{18}$

In a seminal contribution that brought scholarly attention back to the issue of business power, Jacob Hacker and Paul Pierson argue that structural business power should be conceived as "a variable, not a constant." ${ }^{19}$ In contrast to Vogel, they insist that variation in business power shouldn't be taken as evidence of its absence. Rather than seeing structural power as a fixed and unchanging attribute of capitalist countries as Lindblom does, they point out that such power can and does vary over time. They offer the example of the New Deal reforms of the 1930s, which reduced the structural power of American business by centralizing key aspects of social policy. By partly neutralizing the effects of federalism, these reforms made it harder for employers to play individual state governments off one another against threat of exit.

${ }^{15}$ Hall and Soskice 2001.

${ }^{16}$ See, especially, Korpi 2006.

${ }^{17}$ Stephens 1979; Korpi 1983.

${ }^{18}$ See, e.g., Korpi 2006.

${ }^{19}$ Hacker and Pierson 2002, 282. 
Other theorists identify further sources of variation. Culpepper's work, for example, points to variation in business influence due to differences in the political salience of various issues. ${ }^{20} \mathrm{He}$ argues that business actors have more power to influence policy-making and policy implementation in domains characterized by what he calls "quiet politics." When issues become politically salient, and therefore contested in the glare of public attention, it's harder for business interests to prevail in political discourse as public opinion and party politics become more influential. In their subsequent work on bank bailouts, Culpepper and Raphael Reinke ${ }^{21}$ depart from both Lindblom ${ }^{22}$ and Hacker and Pier$\operatorname{son}^{23}$ to argue further that structural power doesn't necessarily operate automatically (through anticipated reactions on the part of policymakers), but can instead be deployed strategically. ${ }^{24}$ Another recent strand of work explores cross-national and cross-sectoral variation in the ability of business to strategically mobilize consumers as a source of influence in conflicts with organized labor and government. ${ }^{25}$

\section{Institutional Sources of Business Power}

Compared to the earlier work, then, recent scholarship has paid more attention to the empirical analysis of business power and its variationacross countries, across issue areas of varying salience, across sectors, and over time. But as the foregoing discussion suggests, contemporary debates still center largely on business power in its classic structural and instrumental manifestations. In so doing they neglect the growing significance of other forms of business power. In particular, the important institutional sources of business power remain undertheorized.

Institutional business power differs in important ways from both structural and instrumental power, although the three complement and enhance one another empirically. ${ }^{26}$ Unlike structural power, institutional power doesn't flow from a firm's position in a market economy, but from its role in the provision of key public goods and services. Such situations don't emerge out of the natural operation of the capitalist economy, as in Lindblom's account. Instead, they're based on pol-

${ }^{20}$ Culpepper 2011.

${ }^{21}$ Culpepper and Reinke 2014.

${ }^{22}$ Lindblom 1977.

${ }^{23}$ Hacker and Pierson 2002.

${ }^{24}$ Culpepper and Reinke 2014; see also Marsh, Akram, and Birkett 2015 on the issue of agency, and Woll 2016 on business power and banking reforms.

${ }_{25}$ Collier, Dubal, and Carter 2018; Thelen 2018; Rahman and Thelen 2019; Culpepper and Thelen 2020.

${ }_{26}$ See also Culpepper 2015 on the link between structural and instrumental power. 
icy decisions that either invite or allow private interests to play a central role in providing crucial collective goods on which society depends. As suggested above, the state makes a conscious decision in some cases to share the regulatory space, resulting in what can be thought of as institutional power through delegation. But there are at least two other mechanisms through which private actors can come to share this space. One is through deregulation: the state's retreat-partial or wholesalefrom the provision of some public function, which it cedes to private actors, often in the supposed interest of greater efficiency. Another mechanism is by accretion, where private actors acquire power by taking the initiative to move into a policy arena previously dominated by the state, or into an emerging arena where the role of the state is still limited, and gradually assume a central intermediating role (with the state sometimes legitimating the move after the fact).

Whatever its provenance, institutional business power can be defined as power flowing from the entrenched position of business actors in the provision of essential public functions or services. As we define it, the institutional power of business can be considered to occupy a space at the intersection of structural and instrumental power. To some extent, the different sources of business power are complementary to each other, in the sense that one source can be tapped to increase power in another. When states share power with private actors in providing key public services or in executing key public functions, they expose themselves to the threat of holdup and exit-features this form of power shares with structural power. Typically, sharing space in this way also requires business actors to be involved in policy-making and implementation in these areas, inviting them into the realm of "quiet politics," in which their influence on policy-making is particularly strong. ${ }^{27}$ Once business actors are established as insiders and are regularly included in policy decision-making and implementation, there is much less need for them to resort to traditional lobbying and activism (instrumental power). This illustrates how the different sources of business power act in a complementary manner, akin to communicating vessels.

Our analysis focuses on institutional power as a hitherto undertheorized form of business power. Of course, mixed public-private arrangements can involve many different types of actors, and any government depends on a variety of nonstate actors, such as NGOs, nonprofit universities, and hospitals, whose cooperation is needed to fulfill public functions. In principle, the notion of institutional power can also apply to

${ }^{27}$ Culpepper 2011. 
these other actors, although when nonstate actors depend on the state for financial or other support, and when these quasi-public activities represent their sole function, their exit threat is limited, as is their institutional power. ${ }^{28}$ Thus, a central conditioning factor that influences the extent of institutional business power is the availability and credibility of an exit threat on the part of business. A greater exit threat means stronger institutional power of business (and vice versa).

Furthermore, the institutional power of business can vary according to how deeply business actors are entrenched in the architecture of public service provision, or, to put it another way, how much the state has maintained the capacity to deliver these public services without the cooperation of business actors. Both dimensions are related, but only to a certain degree. The institutional power of business is strongest when both conditions obtain - when the state's dependency on the continued involvement of business is high and when the exit threat of business is credible (as business can easily shift its resources elsewhere). To anticipate our empirical case studies below, this situation holds in the case of Germany: employers can simply decide to stop offering apprenticeship training, while the state has limited capacity to set up alternative public training facilities (at least in the short term and on a large scale). In the case of private schools in Sweden, the state's dependency on the continued involvement of business is lower but still significant, as public and private providers of education exist side by side, with private providers taking a good share of enrollment. Compared to the German case, the exit threat of Swedish private providers is also lower, since they in turn depend on financing from the state. The case of charter schools in the US is the reverse of Sweden in some ways. The state's dependency is lower than in Sweden because private resources mostly supplement public resources - they're targeted not at replacing public resources but at redirecting them toward alternative educational arrangements (notably charter schools) that operate outside the rules applied to traditional public schools. But the exit threat is high in the US case, since the venture philanthropists behind many of these institutions can decide to reinvest their resources elsewhere.

To the extent that the public comes to depend on private actors to provide essential public services, the power relationship between state and private actors is likely to become more asymmetric over time. The

${ }^{28}$ For example, in the US, Planned Parenthood and similar NGOs rely heavily on state funding to perform their core missions, and thus enjoy less institutional power than, say, Boeing, whose contributions to the US defense industry are but one part-albeit a vitally important one-of the company's overall portfolio. We thank an anonymous reviewer for this example. 
corporatism literature recognizes that sharing public space between governments and private business actors opens up the risk of public institutions being "captured" by private interests. Wolfgang Streeck and Lane Kenworthy suggest that governments can neutralize this danger (and minimize the holdup power of business actors' exit threat) by maintaining the state's ability, willingness, and capacity to "threaten direct intervention in case self-government fails to meet its public responsibilities. ${ }^{29}$ The problem is that the credibility of the state's intervention threat is likely to diminish over time. This is because delegating public responsibilities isn't a one-off decision; it sets in motion dynamics that enhance the institutional power of business interests over time in a process of endogenous institutional change. Thus, institutional power often exhibits strong feedback effects (along the lines identified years ago by E. E. Schattschneider and further developed by Paul Pierson, Andrea Louise Campbell, Suzanne Mettler, and others), ${ }^{30}$ in which past policy choices alter the political landscape.

These feedback effects operate on several levels. Relying on private actors to provide the organizational and administrative infrastructure needed to deliver key benefits can lead to the decay (or even an active dismantling) of the state's own independent delivery system, eroding state capacities in this area. Moreover, where private actors assume some of the financing for providing these services, the state will be increasingly hard-pressed to substitute public-private arrangements with full-fledged public institutions. Especially in times of fiscal austerity, the costs of business exit for the state grow over time. Policy feedback effects also occur on the level of organized interests and political elites as new actors emerge on the scene or as established actors adapt their strategies and positions. In addition, normative connotations of existing institutions have feedback effects on the mass public, influencing popular attitudes toward the most appropriate division of labor between public and private sector in fulfilling public responsibilities. ${ }^{31}$

In short, once public responsibilities have been ceded to business actors, who then become integral parts of the governance and delivery structures of key collective goods and services, the government becomes de facto dependent on the business actors' continued commitment to providing those services. Publicly accountable policymakers in democratic polities can scarcely abdicate their responsibility to provide

\footnotetext{
${ }^{29}$ Streeck and Kenworthy 2005, 455.

${ }^{30}$ Schattschneider 1935; Pierson 1993; Mettler 2011; Campbell 2012.

${ }^{31}$ Busemeyer and Iversen 2014; Lerman 2019; Pierson 1993.
} 
such public services as education, whereas private actors are only motivated to participate as long as it's in their interest to do so. Loathe to risk any disruption in essential public services, policymakers will face ever-stronger incentives to attend to the interests of business in order to maintain private actors' commitment to keep up their side of the bargain.

In sum, the government could, in theory, reduce its dependency by reverting to full-scale public provision. But in practice, reclaiming lost territory becomes more difficult over time as path dependency and lock-in effects increase the economic and political transaction costs implied in such a shift. Not only would the state have less institutional and administrative capacity to do so, it would also face a different political landscape. This arena is populated with new kinds of private actors supported by the government itself, and policymakers may find that the mass public's expectations have changed regarding the balance between public and private provision. In short, once private actors are established and involved in the provision of crucial public goods and services, they're likely to remain on the scene and influence future policymaking processes.

\section{EMPIRICAL ILLUSTRATIONS}

In this section, we offer some short case studies to illustrate our argument. We don't intend these empirical examples to provide a fullfledged test of our theory, nor do we present detailed analyses of the cases. Rather, we aim to demonstrate the usefulness of the notion of institutional business power in broad strokes, highlighting how it differs from both structural and instrumental business power and also how it draws on and blends elements of both.

We focus on education policy because there's no structural imperative that requires business to be involved in providing education. Indeed, education is in many ways a quintessentially public function, and one for which the state often assumes exclusive or at least dominant responsibility. We wouldn't expect a priori business actors to have particularly strong power resources in this field as compared to, for instance, financial or labor markets. So finding indicative evidence for a significant and increasing role of business actors in education suggests that similar dynamics could be at work in other policy fields as well. Empirically, education provides illustrations of each of the mechanisms of change noted above; in all three cases, the result is a significant increase in the institutional power of business. 


\section{Institutional Power through Delegation: Vocational TRAINING IN GERMANY}

The case of Germany provides a clear illustration of the first mechanism, delegation. The dual model of apprenticeship training (that is, the combination of workplace-based training in firms and theoretical education in vocational schools) has a long tradition in Germany, though it wasn't fully entrenched in the law until the late 1960s. An extremely popular system, it enjoys the support of organized business and labor groups, plus that of political parties across the spectrum. ${ }^{32}$ The system provides key institutional support for Germany's highly competitive export sector, and it is widely considered a particularly successful public-private partnership. It rests on a well-developed infrastructure in which the education and training of young people is delegated to training firms that are held to standards set jointly by employers, unions, and government actors. Germans don't consider it problematic to have employers directly involved in the crucial area of youth education and training. On the contrary, this involvement is seen as an asset because it mitigates market failures, such as insufficient training, and ensures a close match between training and the skill needs of actual firms.

Hence - and it's important to emphasize this — the German apprenticeship training system shows that from a normative point of view, having business actors involved in providing public functions isn't inherently good or bad. Business involvement can have beneficial or detrimental side effects for society as a whole, and in many ways the German apprenticeship system is a classic example of arguments about the benign, indeed positive, influence that organized business sometimes exercises in coordinated market economies. Yet these characterizations shouldn't obscure the immense power wielded by business in this system, which goes back to one simple and foundational fact: at its core, the apprenticeship system relies on employer voluntarism in what is still a market-based system. This means that firms ultimately decide whether to hire apprentices in a given year and if they do decide to hire, in which occupations the apprentices will be trained. Even though political actors are constantly cajoling firms to hire more apprentices-especially when there's a shortage of training slots on the apprenticeship market - they can't compel them to do so.

The German government relies on the private sector to train a significant share of the country's youth through the apprenticeship system.

\footnotetext{
${ }^{32}$ Baethge 2008; Busemeyer 2012; Thelen 2004.
} 
Currently, about five hundred thousand youths enter into a firm-based apprenticeship each year, roughly the same as the number of young adults who take up university studies. ${ }^{33}$ This arrangement gives employers significant institutional power. As firms' participation in the training system is crucial for it to function, employers and their associations can credibly claim that the institutional environment must be molded in a way that boosts or at least preserves their involvement. The institutional power of business depends partly on market conditions. It is likely to be lower when there are shortages of apprenticeship candidates, and higher when there's a lack of training places. Although German employers have recently complained about a shortage of skilled labor, beginning in the 1970s, the German apprenticeship market has generally been characterized by chronic shortages of training slots ${ }^{34}$ and mounting problems with matching the pool of applicants to the slots available. Thus, employer participation in the training of young people becomes a rationed resource, and others involved in the system - state actors and the unions - develop a joint interest in maintaining and nurturing it.

The institutional power of German employers in this system isn't just a theoretical possibility. It has been wielded to great effect to both preserve firm autonomy in this area and to extract concessions from the system's other stakeholders. In the 1970s, a shortage of training slots led the social democratic government to openly consider moving toward a more statist model by strengthening vocational schools and establishing a levy-grant scheme that would require nontraining firms to contribute to a common training fund. ${ }^{35}$ But as conditions worsened in the apprenticeship training market, policymakers became increasingly worried about maintaining employers' involvement in the system. The association representing all the business and employers' associations in the field of training opposed the reforms on the grounds that they "would significantly impede firm-based apprenticeship training and thereby endanger the number of needed and available training places in the future." ${ }^{36}$ Faced with such resistance and the prospect of alienating training firms, the government backed down, scrapping the most contentious reform plans. ${ }^{37}$

As an alternative, employers voluntarily offered to accept more ap-

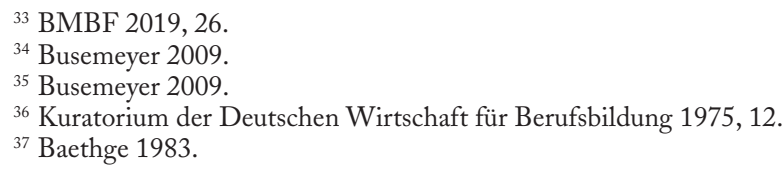


prentices, especially after the 1982 change to a more business-friendly coalition government led by Helmut Kohl and the Christian democrats. The new government cooperated with the peak employers' association to mobilize support among individual firms to increase the number of training slots. This defused the tense situation in the apprenticeship training market. In a prominent government policy statement at the beginning of his tenure, Chancellor Kohl proclaimed an "apprenticeship guarantee," promising a training slot for every willing and able youth. ${ }^{38} \mathrm{He}$ then proceeded to implore business to produce an additional thirty thousand training slots. ${ }^{39}$

In exchange for the employers' voluntarily overcoming the shortfall of training places, the government dropped the previous administration's ambitious reform agenda. The new federal education minister, Dorothee Wilms, heavily criticized the more statist and interventionist threats of the social-liberal government of the 1970s, and emphasized the government's goal of reducing "regulation, bureaucracy and administration on all fronts." ${ }^{40}$ She suggested further that statist intervention would be counterproductive, harming the willingness of business to participate in training. ${ }^{41}$ In an official political statement, the government made clear its position on the division of labor between state and business in this area: "Business has taken over a societal responsibility in providing vocational education and training, which it manages largely as a matter of self-responsibility." ${ }^{2}$

To facilitate the efforts of business actors in discharging these responsibilities, and to enhance the incentives for firms to participate in apprenticeship training, the government undertook a number of reforms aimed at removing "unnecessary bureaucratic regulations." ${ }^{33}$ It promoted principles like the "independence of training firms" and avoided "statist-bureaucratic forms of steering." ${ }^{4}$ For example, the government loosened regulations regarding working time for youths as well as those regarding health and safety concerns; deregulated policies regarding the training of firm-based training personnel; and, in the 1990s when the

\footnotetext{
${ }^{38}$ Kohl 1983, 299.

${ }^{39}$ The private sector delivered, increasing the number of training slots even beyond Kohl's promises. The government offered thanks for "special efforts in securing a sufficient number of training slots"; Deutscher Bundestag 1983, 1.

${ }^{40}$ Wilms 1986, 17.

${ }^{41}$ In the minister's own words: "I have never doubted that the commitment of business to vocational education and training is best nurtured and supported without leveling a policy of "the big stick." Cf. Wilms 1986, 19.

42 Deutscher Bundestag 1983, 3.

${ }^{43}$ Deutscher Bundestag 1983, 3.

${ }^{44}$ Deutscher Bundestag 1989, 1-2.
} 
structural crisis on the apprenticeship market persisted, significantly weakened requirements for training firms to give credit to apprentices for previous training acquired outside the firm. ${ }^{45}$

A subsequent switch in government to a left-wing "red-green" coalition of social democrats and the Greens in 1998 didn't fundamentally change the trajectory of the German vocational training regime. Faced with another severe lack of slots, the government again raised the possibility of more interventionist measures, including a levy on nonparticipating firms and the establishment of a fully school-based alternative alongside the firm-based apprenticeship system. But the idea of a school-based alternative met with intense opposition from the employers' camp. A representative of the powerful German Chamber of Industry and Commerce demanded that the idea of a school-based equivalent be withdrawn as a "necessary condition" for further negotiations between government and employers on dealing with the apprenticeship market crisis. ${ }^{46}$

Faced with these and similar threats by employers to withdraw from the training system, the government dropped its more interventionist proposals and again adopted supportive measures geared toward strengthening positive incentives for firms to participate in training. These included lowering the qualification requirements for firm-based training personnel and giving firms more leeway in setting firm-specific training content. ${ }^{47}$ Like his conservative predecessors, Chancellor Gerhard Schröder pursued a voluntarist training pact with employers, one that accommodated their demands for greater flexibility in organizing training. Even as his government was making significant concessions to business, the chancellor could be heard imploring firms to fulfill their obligation to give youth a chance to acquire skills. ${ }^{48}$

It is telling - and most important for our argument - that by the late 1990s and early 2000s, the government met mounting resistance not just from business interests, but also from other organized stakeholders and from within its own camp, as trade unions and regional leaders of the ruling social democrats also rallied to defend the existing system. ${ }^{49}$ For example, in the case of the proposal to introduce a school-based alter-

\footnotetext{
${ }^{45}$ Busemeyer 2009, 118, 141.

${ }^{46}$ Busemeyer 2009, 155. Another representative of the same organization argued that a training levy would lead "to a complete take-over of dual training by the state"; quoted in Busemeyer 2009, 153.

${ }^{47}$ Busemeyer 2009, 147-68.

${ }^{48}$ Ralf Neukirch, Michael Sauga, and Gabor Steingart, "In Argwohn vereint" [United in Suspicion], Der Spiegel, May 5, 2003, p. 105. At https://magazin.spiegel.de/EpubDelivery/spiegel/pdf /27007516, accessed June 10, 2020.

${ }^{49}$ Busemeyer 2012, 703.
} 
native, almost all the major unions sided with the employers in defending firm-based apprenticeship training against state encroachment. ${ }^{50}$ This move represented a significant reversal of labor's position compared to that of the 1970s. Having lost the earlier battles to enhance the state's role in vocational training, unions had turned their energies toward exerting influence within the existing firm-based system, among other ways, through collective bargaining. ${ }^{51}$ By the 2000s, unions had come around to a full-throated defense of firm-based training, rejecting proposals for the introduction of state alternatives. For example, a 2004 statement by the German Confederation of Trade Unions (Deutscher Gewerkschaftsbund or DGB) made it clear that organized labor opposed greater state presence in this area on the grounds that it would increase "fragmentation" in the country's training regime and lead to a "devaluation" (Entwertung) in the traditional firm-based system. ${ }^{52}$

Over time, then, the entire debate about training reform shifted toward accommodating the needs and desires of business. All talk of training levies and school-based alternatives has vanished from mainstream debates. The most recent major reform to the system, the Federal Law on Vocational Education and Training in 2004-2005, aims instead at "stopping the trend towards statism in vocational training" by recognizing the "special responsibility" of business and government to "provide a sufficient supply of attractive training places." ${ }^{53}$ What's more, the parties supporting the reform (the governing social democrats and Greens, and the Christian democrats in the opposition) stated jointly, "The modernization of vocational training can only be successful if the number of firm-based apprenticeships does not decline further. Public investments cannot compensate for the decline of firm-based training places." 54

The case of apprenticeship training in Germany raises several points that are important for our argument. One is that business actors draw power from a variety of sources. To be sure, German employers and their associations regularly and openly voiced opposition to policy proposals they saw as contrary to their interests. But this form of instrumen-

${ }^{50}$ Deutscher Gewerkschaftsbund 2004.

${ }^{51}$ IG Metall 1983, 12-13. After criticizing the continued dependence of the number of available training slots on changing market conditions, the union's 1983 position paper states the following goal for the coming years: "It is now becoming more important that we use more than before our own sources of power to secure the availability of training opportunities in those places where they are most in danger: in the firms themselves!" (p. 12).

${ }^{52}$ Deutscher Gewerkschaftsbund 2004, 6.

${ }^{53}$ Fraktionen 2004, 2-3

${ }^{54}$ Fraktionen 2004, 6 . 
tal power was complemented by institutional sources of power, which is wielded in less open and less visible ways and is manifested in how other actors besides business started to embrace the policy positions of employers. Unions and Social Democratic Party leaders came around to defending the autonomy of firms in the training system rather than promoting interventionist policies that might trigger firm withdrawal. Throughout the process, the availability of a credible exit threat-the prospect that firms would simply stop offering training slots-strongly influenced the institutional power of German employers in the apprenticeship system, allowing them to hold the state at bay and to secure policy concessions that reflected their interests.

\section{Institutional Power through Deregulation: Education REFORM IN SWEDEN}

Sweden provides an example of an alternative mechanism through which private interests acquire institutional power in the area of education: deregulation. In the early 1990s, key areas of the Swedish welfare system - in particular, education and care services-were opened to competition by private providers. These changes were inspired by a combination of fiscal and political strains, the latter related to growing discontent among the Swedish middle classes for the lack of individual choice. ${ }^{55}$ Although the for-profit sector has expanded gradually, the long-term changes have been significant. Prior to the 1990s, social policy in these areas was "organized as a virtual public monopoly of carefully planned and standardized services," with private providers playing almost no role. ${ }^{56}$ The system was premised on core values that were quintessentially social democratic: high-quality, subsidized, and uniform public services were guaranteed to all citizens as a matter of right.

The reforms of the 1990s represented a major departure from this long-term development trajectory. ${ }^{57}$ In the area of education, the reforms established a voucher regime in which public funds are used to support private "independent" schools. The Swedish approach of establishing a market for educational services is different from full-fledged privatization in that to receive public funding, the independent schools must comply with the national curriculum and other governmental regulations. ${ }^{58}$ To head off the possibility that privatization would fuel ed-

\footnotetext{
${ }^{55}$ See, e.g., Klitgaard 2008; Gingrich 2011.

${ }^{56}$ Blomqvist 2004, 140.

${ }^{57}$ Svallfors 2016; Svallfors and Tyllström 2019.

${ }^{58}$ Bunar 2010.
} 
ucational stratification and inequality, the government also prohibited the schools from explicitly selecting students on the basis of academic ability or socioeconomic characteristics.

Despite careful hedging against potential detrimental side effects, school reform in Sweden created dynamics that have strengthened the institutional power of the new for-profit actors over time. Many of the first independent schools to be founded were small-scale operations, but larger companies have since taken over an ever-greater share of the market. According to Jenny Andersson, by 2014 fully 30 percent of the market was controlled by ten large corporations. ${ }^{59}$ The largest of these corporate groups, AcadeMedia, was purchased in 2010 by EQT, a prominent Swedish venture capital firm; in 2017 EQT sold controlling shares to other investors. ${ }^{60}$ Thus, rather than independent schools catering to the particular educational needs of localities or societal groups, the sector has become dominated by large-scale businesses. Today nearly 25 percent of upper secondary students in Sweden attend voucher schools, of which 85 percent are for-profit (the other 15 percent are faith based). ${ }^{61}$

The entry of private actors has fundamentally changed the playing field in education. Stefan Svallfors argues that Sweden's new "welfareindustrial complex" has become "a formidable power bloc in Swedish politics." ${ }^{2}$ "Large private companies have ... achieved a direct role and stake in the organisation of care and education," giving them and their employers' associations a voice in policy-making in these sectors. ${ }^{63}$ Both Svallfors and Andersson characterize business influence in this area mostly in instrumental terms, emphasizing new "iron triangles" consisting of private providers, elected politicians, and policy entrepreneurs embedded within the bureaucracy itself. Andersson emphasizes that the biggest players in the welfare market enjoy direct access to party elites and maintain active public relations machines. ${ }^{64}$

But the growing institutional power enjoyed by business in these sectors is just as important as these new sources of instrumental power. With privatization, the logic of the system shifted from universalism and egalitarianism toward efficiency and cost effectiveness. This new

${ }^{59}$ Andersson 2014, 124. Similar figures are given in Svallfors and Tyllström 2019, 749.

60 "BRIEF-EQT Sells 12.6 Million Shares in AcadeMedia, Cuts Stake to 12.1 pct." Reuters, September 20, 2017. At https://www.reuters.com/article/brief-eqt-sells-12.6-million-shares-in-ac/brief-eqt -sells-12-6-million-shares-in-academedia-cuts-stake-to-12-1-pct-idUSFWN1M103T, accessed June 10, 2020.

${ }^{61}$ Tyrefors Hinnerich and Vlachos 2016, 4.

${ }^{62}$ Svallfors 2016, 509.

${ }^{63}$ Svallfors 2016, 508.

${ }^{64}$ Andersson 2015, 20. 
logic didn't hold just for the private providers; it also affected public sector providers that were now competing with the private providers. ${ }^{65} \mathrm{As}$ early as 2004, Paula Blomqvist noted the "self-perpetuating quality" of privatization and anticipated that the system would become even more entrenched over time. ${ }^{66}$ She noted that privatization creates its own supporters, not only among the firms that provide these services but also among the users, especially those in high-performing schools and user-friendly care facilities, who can be mobilized to defend the system.

A growing body of work suggests that the privatization of Sweden's welfare services has led to some of the feedback effects foreseen by Blomqvist. Although the issue of profits has become contentious (see below), the presence of private providers per se isn't necessarily seen as problematic. In a representative survey of public opinion on education policy conducted across eight Western European countries in 2014, 70 percent of Swedes agreed or strongly agreed with the statement, "Families should be able to choose freely between public and private schools, independent of income and place of residence." ${ }^{67}$ Only a bare majority of Swedes - 51 percent-agreed with the statement, "The state alone should be in charge of financing and providing education at all levels," while across all eight countries included in the study, 56 percent of respondents agreed with it. ${ }^{68}$ Similarly, in the case of health care services, Anna Bendz finds that support for further privatization increases once users themselves have experienced these services. ${ }^{69}$ And Jonas Edlund and Ingemar Johansson Sevä find that municipalities offering more private options show stronger support for a mixed public-private system. ${ }^{70}$ Thus, the influence of private providers has also grown as consumers have become more invested in the new model. As Andersson points out, the current system doesn't just react to middle-class preferences for "choice," but actively reinforces them. ${ }^{71}$

Moreover, and as in the case of Germany, the growth of the forprofit sector has also affected the positions of interest groups. For example, Gabrielle Meagher and Marta Szebehely show that the position of Kommunal, the Swedish municipal workers' union, flipped over time. ${ }^{72}$ Initially, the union was strongly committed to public provision, but it

${ }^{65}$ Blomqvist 2004, 151; see also Busemeyer and Iversen 2014.

${ }^{66}$ Blomqvist 2004, 152.

${ }^{67}$ Busemeyer et al. 2018; Busemeyer, Garritzmann, and Neimanns 2020.

${ }^{68}$ In addition to Sweden, the other countries are Denmark, UK, Ireland, Germany, France, Italy, and Spain.

69 Bendz 2017.

${ }^{70}$ Edlund and Sevä 2013.

${ }^{71}$ Andersson 2014, 127.

${ }^{72}$ Meagher and Szebehely 2019, 464. 
reversed its position in 2001 to match its leadership's pro-privatization stance. Something similar occurred in the education sector. As Jane Gingrich points out, Swedish teachers' unions have gradually warmed to independent schools, which they see "as offering them greater professional autonomy." ${ }^{73}$ Surveys show that teachers employed by independent schools express more satisfaction with their jobs and management than those employed in municipal schools. ${ }^{74}$

In 2012, a major scandal in Sweden's eldercare industry provoked a public backlash that inspired a broad debate on profits for private providers of welfare services, including in the education sector. The social democratic government that came to power in 2014 established a commission to lead an inquiry into this issue. If anything, the initiative exposed the latent institutional power of private education providers. In 2016, when the so-called Reepalu commission announced a proposal to impose an operating profit cap of 7 percent of working capital, private providers reacted with dire warnings and thinly veiled threats. ${ }^{75}$ One of the country's largest private education providers, Internationella Engelska Skolan, threatened that it would be forced to cease operations if the commission's recommendations were implemented and that it would demand "full compensation for the loss of value that the proposal would entail." ${ }^{76}$ The Swedish Association of Independent Schools (Friskolornas Riksförbund) voiced a similar critique: "The proposal is, in fact, a prohibition on profits and will lead to the closure of the majority of the independent preschools and schools, whether public limited companies, associations or foundations." The association made it clear that "if the investigation's proposal becomes a reality, the municipalities would, at short notice, be forced to accept tens of thousands of students who will be left without school when the independent schools are forced to close down." ${ }^{\prime 7}$

These threats seem to have resonated among policymakers. As Ilmar

${ }^{73}$ Gingrich 2011, 160.

${ }^{74}$ See, e.g., the article in the education news portal Skolvärlden entitled, "Teachers in Independent Schools More Satisfied." At https://skolvarlden.se/artiklar/larare-pa-friskolor-mer-nojda, accessed June 10, 2020. We thank Axel Cronert for drawing our attention to this point.

${ }^{75}$ Meagher and Szebehely 2019, 469.

${ }^{76}$ Claes Lönegård, "Storm av kritik mot Reepalus välfärdsutredning” [Inquiry on Welfare Services Receives Harsh Criticism], Svenska Dagbladet, February 7, 2017. At https://www.svd.se/stormen -mot-reepalu--kritiken-valler-in, accessed June 10, 2020. Thanks to Axel Cronert for this reference and translation.

${ }_{77}$ The response of the Swedish Association of Independent Schools to the commission's proposal was published on the association's website at https://www.friskola.se/2017/02/08/remissvar-ordning -och-reda-i-valfarden-sou-201678/. Similar dynamics played out in other sectors. For example, Håkan Tenelius, a representative of the Association of Private Care Providers, lambasted the idea of a profit cap in a newspaper article entitled, "Stopping Profit Would in Practice Mean Stopping Welfare" (Meagher and Szebehely 2019, 468). 
Reepalu, the government-appointed chair of the commission on limiting profits, recognized, "We would have been in a somewhat easier situation if much of what we are proposing was introduced some twenty years ago." ${ }^{\text {I }}$ In large cities, where private providers have a significant market share and would be most directly affected by disruptions, local policymakers reacted particularly strongly to the (more or less) veiled threats from private providers. Their reaction was a clear indicator of the institutional sources of power that these providers can tap into. For example, the mayors of Stockholm and Norrköping publicly opposed the plan. In an interview that appeared in Dagens industri, Stockholm's mayor drew attention to her city's heavy dependence on private providers in the education and care sectors. Urging the social democrats to look for a concession, she stated, "We must seek a broad compromise that is sustainable over time, where we safeguard tax money and ensure that we get good quality." 79

These developments and the subsequent failure of the profit cap to prevail in parliament resonate with Svallfors and Anna Tyllström's analysis of private provision in Swedish healthcare. They attribute the resilience of private provision to the way in which these private providers create "facts on the ground" and then "strategically [use] their current position and possibilities for exit as a bargaining threat ... [and in this way seek] to beat off threats against their market." 80

In sum, this illustrative case study of Swedish education policy shows that over the last two decades the political arena of social policy-making has tilted significantly in favor of the business interests of private welfare service providers. There's nothing inherent in capitalism that explains this (as structural power accounts would argue). Nor were the privatization reforms of the 1990s a result of lobbying efforts from business actors (instrumental power), since many of the most influential actors simply didn't exist then-rather, they were engendered and empowered by the reforms themselves. But once enacted, the privatization and deregulation of education in Sweden set in motion a self-reinforcing process that transformed the political landscape. It changed public attitudes regarding the division of labor between public and private actors in the delivery of public services, and it empowered new kinds of organized interests that could convert some of their institutional power

${ }^{78}$ Cited in Wallin 2016.

79 Tomas Nordenskiöld and Fredrik Öjemar, "S-revolt mot Reepalus vinsttak" [S-Revolt against Reepalus Profit Ceiling], Dagens Industri, February 1, 2017. At https://www.di.se/nyheter/s-revolt -mot-reepalus-vinsttak/, accessed June 10, 2020. With thanks again to Axel Cronert for the reference and translation.

${ }^{80}$ Svallfors and Tyllström 2019, 755. 
resources into instrumental power to influence future rounds of policymaking, as in the recent attempt to introduce a profit cap. Despite a significant amount of open lobbying in the latter case, this exercise in instrumental power was ultimately made possible by actors being able to mobilize and tap into the institutional sources of power that flow from their entrenched position in the architecture of the increasingly privatized Swedish welfare state.

\section{Institutional Power through Accretion: Venture Philan- THROPY IN US EDUCATION}

The United States illustrates a third mechanism through which private interests secure institutional power in the area of education: a process we call accretion. Accretion occurs when private interests invite themselves into a policy area and over time become increasingly involved in providing crucial public services. The accumulation of power through accretion differs from delegation in that it doesn't always depend on an explicit act of delegation from the state to private actors. And unlike deregulation, increasing private involvement doesn't stem from an initially retreating state, though it can certainly promote a further retreat of the state as a consequence. Instead, the initiative comes from the private actors themselves, but their influence can be facilitated by government and then legitimated and supported by government after the fact. As with the other mechanisms, the growing presence of private actors through accretion reconfigures the policy landscape in ways that can shift the balance of power between the state and private actors in favor of the latter.

To illustrate this dynamic, we discuss the case of education reform in the US, focusing on the role of venture philanthropists (VPs). In recent years, a small number of wealthy individuals and families (Bill and Melinda Gates, Eli and Edythe Broad, the Walton family, and others) have taken up the cause of education reform. Although these philanthropists operate through foundations that are formally independent of the business interests behind them, many have pursued agendas heavily laced with political advocacy, promoting policy changes closely aligned with these interests. ${ }^{81}$ Accretion occurs as vPs promote education reform from the bottom up, funding alternative models of education provision at state and district levels that emphasize school choice and competi-

\footnotetext{
${ }^{81}$ One of the most active players in this space is the Walton Family Foundation, created by an outspoken conservative donor, Sam Walton, who was the founder and CEO of Walmart. Primary and secondary $(\mathrm{K}-12)$ education is "a key portion of [the foundation's] funding and portfolio" (Scott $2009,122)$, with ambitions to enhance school choice and weaken teachers' unions, among other goals.
} 
tion, while often sidestepping traditional stakeholders, such as teachers' unions. Once this alternative model of education provision takes hold, often in the concrete form of new charter schools, policy feedback occurs as students, parents, policymakers, and sometimes administrators and teachers themselves become invested in it. To the extent that these new private actors become entrenched in the education landscape, instrumental business power is increasingly converted into institutional power as policymakers come to depend on the continued commitment of private actors to education provision.

As Sarah Reckhow argues, the growing influence of this new generation of VPs in the US education system originated in a set of favorable conditions. ${ }^{82}$ The effects of the Bush administration's No Child Left Behind law had shaken public confidence in the existing school system and encouraged greater experimentation at state and local levels. ${ }^{83}$ This aftermath encouraged donors with strong reform agendas to shift away from directly assisting public schools and to move toward funding and promoting various "jurisdictional challengers," that is, organizations like charter schools and other models "that compete with or offer alternatives to public sector institutions." ${ }^{84}$ Meanwhile, the emergence of nationally oriented networks - including charter management organizations (CMOs) and the influential nonprofit organization, Teach for America-created the infrastructure through which big donors could channel their energies and wealth. ${ }^{85}$

Today's VPs are more likely than their predecessors to engage in strategic charitable giving, seeking out projects that align with their own values and business models. ${ }^{86}$ Existing research shows that education philanthropy has become increasingly concentrated on jurisdictions in which donors can exert the most influence on policy-making. For example, as Reckhow's work shows, vPs favor cities with strong executives, where education is subject to mayoral or state control as opposed to control by elected school boards in which teachers' unions may exercise stronger influence. ${ }^{87}$ Leslie Finger's research suggests that VPs also target cities that exhibit financial need and are thus more amena-

${ }^{82}$ Reckhow 2012.

${ }^{83}$ See Scott 2009.

${ }^{84}$ Reckhow and Snyder 2014, 186. Reckhow and Snyder find that the top-fifteen education philanthropies increased their support for charters from 3 to 16 percent between 2000 and 2010, while reducing their financial support for district schools from 16 to 8 percent (p. 190)

${ }^{85}$ Reckhow 2012, 23-25; see also Reckhow and Snyder 2014, 187; Quinn, Tompkins-Stange, and Meyerson 2014. On Teach for America — and the role of philanthropic support in fueling its rise - see Baxendale 2020, esp. chaps. 5 and 7.

${ }^{86}$ Reckhow 2012, 31, 36; Scott 2009, 115, 119.

${ }^{87}$ See Reckhow 2012, chap. 2. 
ble to philanthropic influence ${ }^{88}$ and, in our words, are more dependent on continued financial contributions from private actors. Hence, even though vPs commonly employ instrumental power to enter the policy area of education, they appear to target states and cities where the likelihood of their accumulating institutional power is greater in the long term.

Many of the big philanthropists have channeled their resources into promoting charter schools- publicly funded but independently operated schools that aren't bound by the rules that apply to traditional public schools, such as those regarding hours of operation and teacher hiring and pay. Although charters account for only about 6 percent of total public school enrollment across the US, their share in specific, targeted cities and districts is far higher, reaching between 40 and 50 percent in some districts in Michigan, Missouri, Indiana, and Washington, D.C. ${ }^{89}$ In cities with the highest share of charters, the imprint of VP influence is often significant and palpable.

One of the most prominent (and contentious) cases is New Orleans. As a result of a major school reform undertaken after Hurricane $\mathrm{Ka}-$ trina, nearly 95 percent of the city's children are enrolled in charter schools, by far the largest share of any US city. Venture philanthropists played a key role in rebuilding the city's educational infrastructure, and critics suggest that post-Katrina education policy "was largely dictated by the charter establishment and a handful of its wealthy donors." 90 The Walton Family Foundation figured-and still figures - especially prominently in this transformation, providing grants of between $\$ 100,000$ and $\$ 350,000$ to charter startups in the city. ${ }^{91}$ Although some observers see school reform in New Orleans as a "shining success," others consider it a corporate "take over." ${ }^{2}$ Love it or hate it, the role of vPs in the city's educational makeover is undisputed. Furthermore, to the extent that VPs contribute essential financial resources to the school system, public policymakers increasingly depend on the continued contribution of private actors.

The spread of charter schools in other major cities is also a result of active philanthropic work, that is, the exercise of instrumental power,

\footnotetext{
${ }^{88}$ Finger 2018.

${ }^{89}$ Arianna Prothero, "Six Districts where 40 Percent or More of Students Attend Charter Schools," Education Week, November 10, 2015. At http://blogs.edweek.org/edweek/charterschoice/2015/11 /six_districts_where_40_percent_or_more_of_students_attend_charter_schools.html, accessed June 10, 2020.

${ }^{90}$ Gabor 2019.

91 Gabor 2019.

${ }^{92}$ Admirers include Moe 2019, while Gabor 2019 is an outspoken critic.
} 
which is followed by accumulating institutional power as private actors become entrenched in the system. The latter is evidenced by policy feedback effects and growing support for private provision among stakeholders and the mass public, even though a great deal of what VPs are doing remains controversial-especially when it sidelines teachers' unions. When conflicts with policymakers over such issues push into the open, the capacity to tap into institutional power to mobilize allies, such as parents who've grown attached to the services they provide, becomes more manifest.

One high-profile example of this dynamic is the 2014 conflict in New York City between the newly elected mayor Bill de Blasio and Eva Moskowitz, the founder of Success Academy Charter Schools, whose board includes a number of prominent venture philanthropists. ${ }^{93}$ De Blasio, a strong supporter of traditional public schools and teachers' unions, sought to limit the expansion of the Moskowitz network by partly taking back his predecessor Michael Bloomberg's decision to grant space to a number of Success Academy schools. The conflict precipitated a showdown in which a procharter advocacy group, Families for Excellent Schools (funded in part by the Walton Family Foundation), rallied to Moskowitz's defense. During the conflict, Moskowitz shut down Success Academy for a day after alerting parents that "no alternate arrangements would be made for their kids." "Instead of school that day, parents and children were directed to waiting buses (also paid for by Families for Excellent Schools) that took them to participate in demonstrations in Albany. Responding to the more than ten thousand families who gathered at the state capitol, Governor Andrew Cuomo announced, "We will save charter schools!" Shortly thereafter, he enacted legislation that would guarantee space for these schools. ${ }^{95}$

As Jay Greene points out, this case shows "how beneficiaries of choice could be mobilized to defend and expand the program.... If foundations had not initially subsidized the development of charter schools in New York and elsewhere, there would not have been a thriving charter sector with thousands of enrolled students. And if foundations had not supported the organizations that helped mobilize those beneficiaries of charters into an organized interest, constituents may not have turned out in such large numbers and parlayed that strength into victory in Albany. ... Before the foundations took action, these constituents did not know they could benefit from this change and could not be organized to

${ }^{93}$ This example is based on Bergner 2014; see also Greene 2015, 17-18.
${ }^{94}$ Bergner 2014.
${ }^{95}$ Bergner 2014 .

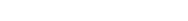


fight for it." ${ }^{" 96}$ Although this kind of open confrontation between state and private actors may look like the exercise of instrumental power, such lobbying actions are only feasible when private actors can also rely on institutional sources of power. The extent to which foundations and related organized interest groups could mobilize parents depended on the feedback effects created by past policy decisions - allowing and even promoting the establishment of charter schools-on mass public opinion and on organized interests like Families for Excellent Schools.

Beyond contributing to the spectacular rise in charter schools, philanthropic funding is often crucial to their continued operation. Despite ambitions to become self-sustaining, many of the CMOs that manage the largest charter networks still rely on private giving. At a 2011 symposium on CMO finance hosted by the University of Washington, not a single attendee could point to a CMO that was fully self-supporting. ${ }^{97}$ One "well-known" (albeit unidentified) CMO in California "required an infusion of $\$ 700,000$ in private funding to prevent financial collapse." 98 In some cities, philanthropy dollars are also used to supplement the salaries of top school-district officials. ${ }^{99}$ These examples demonstrate the continued reliance of many communities on private actors whose contributions can't easily be replaced by (nonexistent) public funds.

As in the other two cases, in the US case we see self-enforcing dynamics that over time have enhanced the institutional power of VPs and the activities and organizations they underwrite. Chronically underfunded urban schools often leap at the chance to secure philanthropic funding, and in such cases, as Reckhow notes, some of the most powerful feedback effects relate to the way in which vP funding reconfigures interest-group coalitions. By empowering new actors while displacing others, these feedback effects alter the education policy landscape. ${ }^{100}$ As in Sweden, the entry of these new actors has changed the public-private mix. In the US, the market logic that animates the CMOs and the charter schools they operate has spread as the public schools that now compete with them embrace some of the same principles. ${ }^{101}$ In response

${ }^{96}$ Greene 2015, 17-18.

${ }^{97}$ Lake and Demeritt 2011, 3

${ }^{98}$ Hall and Lake 2011.

${ }^{99}$ Reckhow 2012, 154.

${ }^{100}$ Reckhow 2012, 7-8.

${ }^{101}$ Such competition is promoted especially by the so-called Portfolio Management model, which has been implemented in many large cities that have a large share of charters. Schools whose performance (typically evaluated by student testing) improves are rewarded with more funding, while poorly performing schools are either starved of additional funds or closed. Cities with Portfolio Management also offer parents a single clearinghouse (unified enrollment system) so that they may go to the same place to enroll their children, either in a charter or a traditional public school. 
to widespread popular dissatisfaction with the status quo and propelled by the tentative support or benign neglect of policymakers and other state actors, VPs have become increasingly involved and invested in US education policy. Indeed, their influence in this area is now taken for granted: in a survey of about two hundred education policy experts, Bill Gates was named the most influential individual in US education policy - ahead of the secretary of education. ${ }^{102}$

To be sure, as Janelle Scott notes, many VP-sponsored programs have had undeniably positive effects in cities where schools have failed to serve children well. At the same time, it's clear that these trends give private interests more opportunity to put their stamp on the American education system while avoiding the usual democratic checks and balances. ${ }^{103}$ With regard to our argument, it's not important to debate whether the influence of private actors in education is beneficial or detrimental for the system as a whole, but rather to highlight how the entrenchment of new actors in educational governance has deeply transformed this policy field by cultivating alternative models that now occupy a significant place in the educational landscape. vPs have gained growing institutional power as communities become dependent on their continued commitment of fiscal resources and political support over time. Policymakers who openly question VP involvement in education policy face significant political backlash, not only from the private business actors themselves, but also from the growing group of supporters among the general population.

\section{Conclusions}

The three cases examined here show the mechanisms through which private interests have become central actors in education, one of the most important areas of public life. Although we've used the case of education as an illustration, we posit that our argument about institutional sources of business power should also apply to other policy areas and types of public-private partnerships. The paths to power documented here vary-through delegation, deregulation, and accretion-but the result in each case is a growing dependence of the state on private actors to deliver key public goods in the context of complex public-private partnerships. Whether this state of affairs ultimately improves the performance of education systems or drives new forms of inequality is an

\footnotetext{
${ }^{102}$ Reckhow 2012, 12. The current US Secretary of Education, Betsy DeVos, is herself a VP and a longtime advocate of school choice and public funding for private religious schools.

${ }^{103}$ Scott 2009, 128; Reckhow 2012, 143-45.
} 
empirically contested question, well beyond the scope of this article. Rather, we emphasize that recent developments in the German, Swedish, and US education systems all point to the importance of institutional power and its distinctive features as a significant yet undertheorized variety of business power.

This type of power emerges at the intersection of the instrumental and structural power of business, but it is distinct from both. It is different from structural power because institutional power isn't the same in all capitalist economies. Instead, it depends on the degree to which business actors have become entrenched in the institutional frameworks of different countries and, more specifically, different policy areas. Thus, while arguments about the structural power of business have been vulnerable to the criticism that business power varies across countries and across time, conceptualizing business power as institutional (or institutionalized) power helps us to understand such variation.

Institutional power also differs from instrumental business power because it points to the power of business in effectively setting the agenda of policy-making without having to rely on persuading politicians directly. Instead, as a form of power that flows as a feedback effect from the prevailing status quo, institutional business power enhances the dependency of political actors and of the mass public (as consumers of the public services provided by private actors) on the continued commitment of these actors to hold up their side of the deal. Therefore, institutional business power can also shape the attitudes and preferences of collective political actors and the mass public. Compared to open conflict or even backroom deals, it's a more effective way for business to prevail in political struggles.

Furthermore, a crucial difference between institutional power and both structural and instrumental power is that the forces of path dependency and policy feedback can enhance the power of business over time without active lobbying. Even if business and governments were to start out in a relationship of "reciprocal dependence," 104 the balance is likely to tilt in favor of business interests over time. The reason for this is simple: even where business actors are incorporated into mixed public-private partnerships, they will only stay involved as long as it's in their interest to do so. Once private actors are deeply entrenched in providing crucial public goods and services, policymakers and the mass public have good reason to avoid measures that could cause these actors to retreat or withdraw. If anything, political actors face strong in-

${ }^{104}$ Culpepper 2015, 397. 
centives to accommodate business interests to keep them committed to the public-private arrangement.

In closing, we note that the valence attached by different observers to the developments in education we've outlined above-whether these are viewed as positive or negative-will clearly vary, depending on one's ideological leanings. Our objective isn't to adjudicate the normative debates but rather to elucidate an important and underappreciated source of business power. By identifying a significant and growing source of business influence and specifying the mechanisms through which such influence can take root and grow, this article makes an important contribution to the scholarly and public debates about the sources and the dynamics of business power in advanced capitalism.

\section{REFERENCES}

Andersson, Jenny. 2014. "Losing Social Democracy: Reflections on the Erosion of a Paradigmatic Case of Social Democracy." In David J. Bailey, Jean-Michel De Waele, Fabien Escalona, and Mathieu Vieira, eds., European Social Democracy during the Global Economic Crisis: Renovation or Resignation? Manchester, UK: Manchester University Press.

Andersson, Jenny. 2015. "Explaining Neoliberalism in Sweden: The Rise of the Welfare Industrial Complex." Paper presented at the 22nd International Conference of Europeanists, Paris, July 10.

Bachrach, Peter, and Morton S. Baratz. 1962. "Two Faces of Power." American Political Science Review 56, no. 4: 947-52. doi: 10.2307/1952796.

Baethge, Martin. 1983. "Berufsbildungspolitik in den Siebziger Jahren: Eine Lektion in ökonomischer Macht und politischer Ohnmacht." In Antonius Lipsmeier, ed., Berufsbildungspolitik in den 70er Jahren: Eine kritische Bestandsaufnahme für die 80er Jabre. Wiesbaden, Germany: Franz Steiner Verlag.

Baethge, Martin. 2008. "Das Berufliche Bildungswesen in Deutschland am Beginn des 21. Jahrhunderts." In Kai S. Cortina, Jürgen Baumert, Achim Leschinsky, Karl Ulrich Mayer, and Luitgard Trommer, eds., Das Bildungswesen in der Bundesrepublik Deutschland. Reinbek, Germany: Rohwohlt.

Baxendale, Helen. 2020. "Teach for America as Institutional Subversive? Structure and Agency in the Contemporary Politics of American Education Reform." Ph.D. diss., Blavatnik School of Government, University of Oxford.

Bendz, Anna. 2017. "Empowering the People: Public Responses to Welfare Policy Change." Social Policy E Administration 51, no. 1: 1-19. doi: 10.1111 /spol.12148.

Bergner, Daniel. 2014. "The Battle for New York Schools: Eva Moskowitz vs. Mayor Bill de Blasio." New York Times Magazine, September 3. At https:// www.nytimes.com/2014/09/07/magazine/the-battle-for-new-york-schools -eva-moskowitz-vs-mayor-bill-de-blasio.html, acessed June 10, 2020.

Blomqvist, Paula. 2004. "The Choice Revolution: Privatization of Swedish Welfare Services in the 1990s." Social Policy E Administration 38, no. 2: 139-55. doi: 10.1111/j.1467-9515.2004.00382.x. 
BMBF. 2019. Berufsbildungsbericht 2019. Bonn, Germany: Bundesministerium für Bildung und Forschung.

Bunar, Nihad. 2010. "The Controlled School Market and Urban Schools in Sweden." Journal of School Choice 4, no. 1: 47-73. doi: 10.1080/15582151003626418.

Busemeyer, Marius R. 2009. Wandel trotz Reformstau: Die Politik der beruflichen Bildung seit 1970. Frankfurt am Main, Germany: Campus Verlag.

Busemeyer, Marius R. 2012. "Business as a Pivotal Actor in the Politics of Training Reform: Insights from the Case of Germany." British Journal of Industrial Relations 50, no. 4: 690-713. doi: 10.1111/j.1467-8543.2012.00900.x.

Busemeyer, Marius R., Julian L. Garritzmann, Erik Neimanns, and Roula Nezi. 2018. "Investing in Education in Europe: Evidence from a New Survey of Public Opinion." Journal of European Social Policy 28, no. 1: 34-54. doi: 10.1177/09 58928717700562.

Busemeyer, Marius R., Julian L. Garritzmann, and Erik Neimanns. 2020. A Loud but Noisy Signal? Public Opinion and Education Reform in Western Europe. Cambridge, UK: Cambridge University Press.

Busemeyer, Marius R., and Torben Iversen. 2014. "The Politics of Opting Out: Explaining Educational Financing and Popular Support for Public Spending." Socio-Economic Review 12, no. 2: 299-328. doi: 10.1093/ser/mwu005.

Campbell, Andrea Louise. 2012. "Policy Makes Mass Politics." Annual Review of Political Science 15: 333-51. doi: 10.1146/annurev-polisci-012610-135202.

Collier, Ruth Berins, V. B. Dubal, and Christopher L. Carter. 2018. "Disrupting Regulation, Regulating Disruption: The Politics of Uber in the United States." Perspectives on Politics 16, no. 4: 919-37. doi: 10.1017/S1537592718001093.

Culpepper, Pepper D. 2011. Quiet Politics and Business Power: Corporate Control in Europe and Japan. Cambridge, UK: Cambridge University Press.

Culpepper, Pepper D. 2015. "Structural Power and Political Science in the PostCrisis Era." Business and Politics 17, no. 3: 391-409. doi: 10.1515/bap-2015-0031.

Culpepper, Pepper D., and Raphael Reinke. 2014. "Structural Power and Bank Bailouts in the United Kingdom and the United States." Politics E Society 42, no. 4: 427-54. doi: 10.1177/0032329214547342.

Culpepper, Pepper D., and Kathleen Thelen. 2020 "Are We All Amazon Primed? Consumers and the Politics of Platform Power." Comparative Political Studies 53, no. 2: 288-318. doi: 10.1177/0010414019852687.

DeutscherBundestag.1983. UnterrichtungdurchdieBundesregierung:Berufsbildungsbericht 1983. BT-Drucksache 10/334.

DeutscherBundestag. 1989. UnterrichtungdurchdieBundesregierung:Berufsbildungsbericht 1989. BT-Drucksache 11/4442.

Deutscher Gewerkschaftsbund. 2004. Reform der Berufsbildung. Berlin, Germany: DGB-Bundesvorstand.

Edlund, Jonas, and Ingemar Johansson Sevä. 2013. "Is Sweden Being Torn Apart? Privatization and Old and New Patterns of Welfare State Support." Social Policy E' Administration 47, no. 5: 542-64. doi: 10.1111/spol.12021.

Esping-Andersen, Gøsta. 1990. The Three Worlds of Welfare Capitalism. Cambridge, UK: Polity Press.

Finger, Leslie K. 2018. "Giving to Government: The Policy Goals and Giving Strategies of New and Old Foundations." Interest Groups Eं Advocacy 7, no. 2: 312-45. doi: 10.1057/s41309-018-0042-4. 
Fraktionen. 2004. Entschließungsantrag der Fraktionen von SPD, CDU/CSU und Bündnis 90/Die Grünen im Ausschuss für Bildung, Forschung und Technikfolgenabschätzung zum Gesetzentwurf der Bundesregierung: Entwurf eines Gesetzes zur Reform der beruflichen Bildung. BT-Drucksache 15/3980.

Gabor, Andrea. 2019. “The K-12 Takeover: Big Philanthropy's Bid to Privatize Education." Harper's Magazine. November. At https://harpers.org/archive/2019/11 /the-k-12-takeover-charter-schools-new-orleans/, accessed June 10, 2020.

Gaventa, John. 1980. Power and Powerlessness: Quiescence and Rebellion in an Appalachian Valley. Oxford, UK: Clarendon Press.

Gingrich, Jane R. 2011. Making Markets in the Welfare State: The Politics of Varying Market Reforms. Cambridge, UK: Cambridge University Press.

Greene, Jay P. 2015. "Buckets into Another Sea." In Frederick M. Hess and Jeffrey R. Henig, eds., The New Education Philanthropy: Politics, Policy, and Reform. Cambridge, Mass: Harvard Education Press.

Hacker, Jacob S. 2004. "Privatizing Risk without Privatizing the Welfare State:The Hidden Politics of Social Policy Retrenchment in the United States." American Political Science Review 98, no. 2: 243-60. At https://www.jstor.org/stable /4145310.

Hacker, Jacob S., and Paul Pierson. 2002. "Business Power and Social Policy: Employers and the Formation of the American Welfare State." Politics E' Society 30, no. 2: 277-325. doi: 10.1177/0032329202030002004.

Hall, Kevin, and Robin Lake. 2011. “The \$500 Million Question.” EducationNext 11, no. 1. At https:/www.educationnext.org/the-500-million-question/, accessed October 17, 2019.

Hall, Peter A., and David Soskice. 2001. "An Introduction to Varieties of Capitalism." In Peter A. Hall and David Soskice, eds., Varieties of Capitalism: The Institutional Foundations of Comparative Advantage. Oxford, UK: Oxford University Press.

IG Metall. 1983. Stellungnahmen zu Grundsatzfragen der Berufsbildung III. Frankfurt am Main, Germany: IG Metall.

Katzenstein, Peter J. 1985. Small States in World Markets: Industrial Policy in Europe. Ithaca, N.Y.: Cornell University Press.

Klitgaard, Michael Baggesen. 2008. "School Vouchers and the New Politics of the Welfare State.” Governance 21, no. 4: 479-98. doi: 10.1111/j.1468-0491.2008 .00410.x.

Kohl, Helmut. 1983. "Regierungserklärung vom 4. Mai 1983.” In Klaus Stüwe, ed., Die Großen Regierungserklärungen der deutschen Bundeskanzler von Adenauer bis Schröder. Opladen, Germany: Leske + Budrich.

Korpi, Walter. 1983. The Democratic Class Struggle. London, UK: Routledge \& Kegan Paul.

Korpi, Walter. 2006. "Power Resources and Employer-Centered Approaches in Explanations of Welfare States and Varieties of Capitalism: Protagonists, Consenters, and Antagonists." World Politics 58, no. 2 (January): 167-206. doi: 10 $.1353 /$ wp.2006.0026.

Kuratorium der Deutschen Wirtschaft für Berufsbildung. 1975. Stellungnabme zum Regierungsentwurf für ein neuen Berufsbildungsgesetz. Bonn, Germany: KWB.

Lake, Robin, and Allison Demeritt. 2011. Paying for Scale: Results of a Symposium on CMO Finance. Seattle, Wash.: University of Washington National 
Charter School Research Project, Center on Reinventing Public Education. At https://media.digitalarchives.wa.gov/do/C56376DF34F20AA2422778211 60BFF8A.pdf, accessed June 10, 2020.

Lerman, Amy E. 2019. Good Enough for Government Work: The Public Reputation Crisis in America (and What We Can Do to Fix It). Chicago, Ill.: University of Chicago Press.

Lijphart, Arend. 1999. Patterns of Democracy: Government Forms and Performance in Thirty-Six Countries. New Haven, Conn.: Yale University Press.

Lindblom, Charles E. 1977. Politics and Markets: The World's Political-Economic Systems. New York, N.Y.: Basic Books.

Lindblom, Charles E. 1982. “The Market as Prison.” Journal of Politics 44, no. 2: 324-36. At http://www.jstor.org/stable/2130588.

Lukes, Steven. 1974. Power: A Radical View. Basingstoke, UK: Macmillan.

Marsh, David, Sadiya Akram, and Holly Birkett. 2015. "The Structural Power of Business: Taking Structure, Agency and Ideas Seriously." Business and Politics 17, no. 3: 577-601. doi: 10.1515/bap-2015-0001.

Meagher, Gabrielle, and Marta Szebehely. 2019. "The Politics of Profit in Swedish Welfare Services: Four Decades of Social Democratic Ambivalence." Critical Social Policy 39, no. 3: 455-76. doi: 10.1177/0261018318801721.

Mettler, Suzanne. 2011. The Submerged State: How Invisible Government Policies Undermine American Democracy. Chicago, Ill.: University of Chicago Press.

Moe, Terry M. 2019. The Politics of Institutional Reform: Katrina, Education, and the Second Face of Power. New York, N.Y.: Cambridge University Press.

Panitch, Leo. 1977. "The Development of Corporatism in Liberal Democracies." Comparative Political Studies 10, no. 1: 61-90. doi: 10.1177/001041407701000 104.

Pierson, Paul. 1993. "When Effect Becomes Cause: Policy Feedback and Political Change." World Politics 45, no. 4 (July): 595-628. doi: 10.2307/2950710.

Pierson, Paul. 2004. Politics in Time: History, Institutions, and Social Analysis. Princeton, N.J.: Princeton University Press.

Quinn, Rand, Megan Tompkins-Stange, and Debra Meyerson. 2014. "Beyond Grantmaking: Philanthropic Foundations as Agents of Change and Institutional Entrepreneurs." Nonprofit and Voluntary Sector Quarterly 43, no. 6: 95068. doi: 10.1177/0899764013488836.

Rahman, K. Sabeel, and Kathleen Thelen. 2019. "The Rise of the Platform Business Model and the Transformation of Twenty-First-Century Capitalism.” Politics E' Society 47, no. 2: 177-204. doi: 10.1177/0032329219838932.

Reckhow, Sarah. 2012. Follow the Money: How Foundation Dollars Change Public School Politics. New York, N.Y.: Oxford University Press.

Reckhow, Sarah, and Jeffrey W. Snyder. 2014. "The Expanding Role of Philanthropy in Education Politics.” Educational Researcher 43, no. 4: 186-95. doi: 10 .3102/0013189X14536607.

Rhodes, Jesse H. 2012. An Education in Politics: The Origins and Evolution of No Child Left Behind. Ithaca, N.Y.: Cornell University Press.

Schattschneider, E. E. 1935. Politics, Pressures and the Tariff. New York, N.Y.: Prentice-Hall.

Scott, Janelle. 2009. "The Politics of Venture Philanthropy in Charter School Policy and Advocacy." Educational Policy 23, no. 1: 106-36. doi: 10.1177/08959 04808328531. 
Stephens, John D. 1979. The Transition from Capitalism to Socialism. London, UK: Palgrave Macmillan.

Streeck, Wolfgang, and Lane Kenworthy. 2005. "Theories and Practices of Neocorporatism." In Thomas Janoski, Robert Alford, Alexander Hicks, and Mildred A. Schwartz, eds., The Handbook of Political Sociology: States, Civil Societies, and Globalization. Cambridge, UK: Cambridge University Press.

Svallfors, Stefan. 2016. "Politics as Organised Combat: New Players and New Rules of the Game in Sweden." New Political Economy 21, no. 6: 505-19. doi: 10.1080/13563467.2016.1156662.

Svallfors, Stefan, and Anna Tyllström. 2019. "Resilient Privatization: The Puzzling Case of For-Profit Welfare Providers in Sweden." Socio-Economic Review 17, no. 3: 745-65. doi: 10.1093/ser/mwy005.

Thelen, Kathleen. 2004. How Institutions Evolve: The Political Economy of Skills in Germany, Britain, the United States, and Japan. New York, N.Y.: Cambridge University Press.

Thelen, Kathleen. 2018. "Regulating Uber: The Politics of the Platform Economy in Europe and the United States." Perspectives on Politics 16, no. 4: 938-53. doi: 10.1017/S1537592718001081.

Tyrefors Hinnerich, Björn, and Jonas Vlachos. 2016. “The Impact of UpperSecondary Voucher School Attendance on Student Achievement: Swedish Evidence Using External and Internal Evaluations.” Working Paper no. 2016:9. Uppsala, Sweden: Institute for Evaluation of Labor Market and Education Policy. At https://www.econstor.eu/handle/10419/166010, accessed June 10, 2020.

Vogel, David. 1987. "Political Science and the Study of Corporate Power: A Dissent from the New Conventional Wisdom." British Journal of Political Science 17, no. 4: 385-408. doi: 10.1017/S0007123400004841.

Wallin, Gunhild. 2016. "Profit Limit on Welfare Services Triggers Strong Emotions in Sweden.” Nordic Labour Journal, November 16. At www.nordiclabourjournal .org/nyheter/news-2016/article.2016-11-14.7556677178, accessed February 6, 2020.

Wilms, Dorothee. 1986. "Bildungspolitik im Umbruch.” In Hans-Josef Demuth, ed., Berufsbildung 2000, DIHT-Jubiläum in Ludwigshafen, 30. September 1986. Bonn, Germany: Deutscher Industrie- und Handelstag.

Woll, Cornelia. 2016. "Politics in the Interest of Capital: A Not-So-Organized Combat." Politics E' Society 44, no. 3: 373-91. doi: 10.1177/0032329216655318.

\section{Authors}

Marius R. Busemeyer is a professor of political science and speaker of the Excellence Cluster "The Politics of Inequality" at the University of Konstanz, Germany. His research focuses on comparative political economy, education policy, and attitudes toward the welfare state. He can be reached at marius.busemeyer@ uni-konstanz.de.

KathleEn Thelen is a professor of political science at the Massachusetts Institute of Technology and a permanent external member at the Max Planck Institute for the Study of Societies, in Cologne, Germany. She works on comparative political economy and, recently, the impact of technological change in advanced postindustrial economies. She can be reached at kthelen@mit.edu. 


\section{AcKNOWLEDGEMENTS}

The authors would like to thank Jenny Andersson, Helen Baxendale, Paula Blomqvist, Axel Cronert, Pepper Culpepper, Leslie Finger, Julian Garritzmann, Ursula Hackett, Peter Hall, Alex Hertel-Fernandez, Jette Knudsen, Susanna Loeb, Cathie Jo Martin, Philip Rathgeb, Sarah Reckhow, Aidan Regan, Ben Schneider, Janelle Scott, and Stefan Svallfors, as well as three anonymous reviewers and the editors of World Politics for helpful comments and suggestions.

\section{FundING}

Research by Marius Busemeyer was supported with funding from the Excellence Cluster "The Politics of Inequality," grant no. EXC 2035/1.

\section{Key Words}

business power, charter schools, comparative political economy, corporatism, education, education reform, historical institutionalism, institutional business power, policy feedback, venture philanthropists 